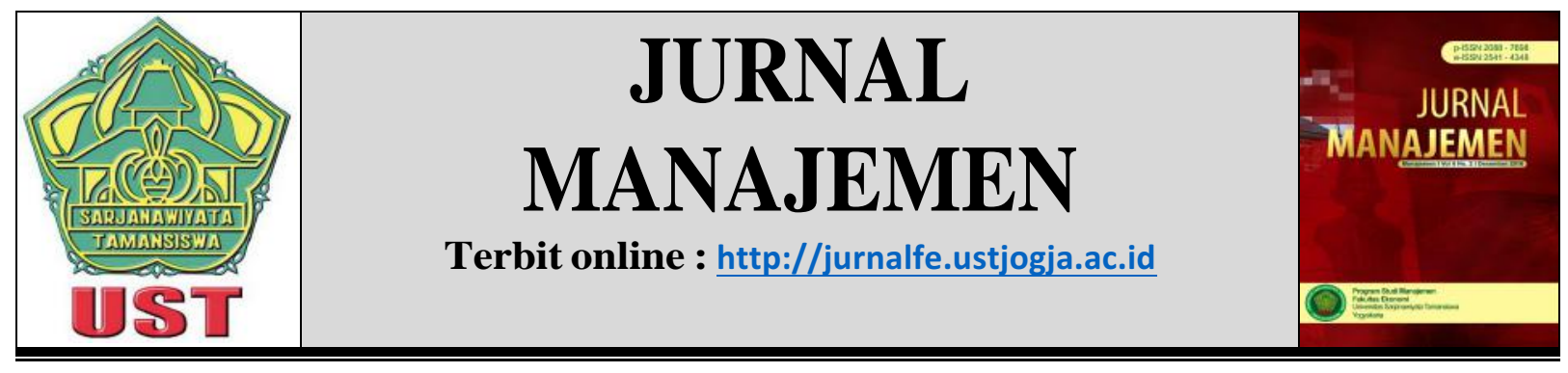

\title{
PURELY VALUE STOCKS \& TINGKAT PENGEMBALIAN SAHAM : EFISIEN ATAU OVER-REACTION? STUDI BERDASARKAN FUNDAMENTAL PERUSAHAAN PADA BURSA EFEK INDONESIA PERIODE 2002-2014
}

\author{
Ahsan Sumantika \\ Manajemen, Fakultas Ekonomi Universitas PGRI Yogyakarta \\ Korespondensi: ahsansumantika@gmail.com
}

\begin{tabular}{|c|c|}
\hline INFO & ABSTRAK \\
\hline Alur I & \multirow{14}{*}{$\begin{array}{l}\text { Penelitian ini bertujuan untuk mengetahui apakah saham-saham value } \\
\text { stocks akan menghasilkan tingkat pengembalian yang lebih tinggi } \\
\text { kendati tetap didapati kinerja keuangan yang buruk pada periode } \\
\text { berikutnya. Kontrol yang digunakan adalah earning growth pada t+1. } \\
\text { Populasi yang digunakan adalah seluruh saham di Bursa Efek Indonesia } \\
\text { periode 2002-2014. Total observasi sampel sebanyak } 290 \text { sampel untuk } \\
\text { purely value stocks dan } 355 \text { sampel untuk purely growth stocks. Teknik } \\
\text { statistika yang digunakan adalah uji beda independen samplet-test. } \\
\text { Hasil penelitian menunjukkan bahwa dalam jangka satu tahun ke depan } \\
\text { saham-saham value stocks menghasilkan tingkat pengembalian yang } \\
\text { lebih tinggi dibanding saham-saham growth stocks tetapi dengan } \\
\text { tingkat signifikansi } 0,06 \text {. Akan tetapi setelah disesuaikan dengan } \\
\text { perubahan fundamental (perubahan laba), saham-saham growth stocks } \\
\text { dengan kinerja baik (purely growth stocks) menghasilkan tingkat } \\
\text { pengembalian yang lebih tinggi dibandingkan dengan saham-saham } \\
\text { value stocks yang berkinerja buruk (purely value stocks) dengan tingkat } \\
\text { signifikansi kurang dari } 0,01 \text {. }\end{array}$} \\
\hline D & \\
\hline & \\
\hline & \\
\hline & \\
\hline & \\
\hline & \\
\hline & \\
\hline & \\
\hline & \\
\hline & \\
\hline & \\
\hline$S t$ & \\
\hline & \\
\hline
\end{tabular}

\section{PENDAHULUAN}

Value stocks merupakan saham-saham yang dihargai rendah karena mencerminkan kinerja yang buruk. Sedangkan growth stocks merupakan saham-saham yang dihargai lebih tinggi karena mencerminkan prospek yang bagus. Akan tetapi, berdasarkan penelitianpenelitian terdahulu (Basu, 1977; Bouman, 1998; Capaul et al., 1993; Fama dan French, 1992, 1995, 1998, 2008; Lakonishok et al.,1994, 2004) mengungkap bahwa value stocks menghasilkan tingkat pengembalian yang lebih tinggi dibanding growth stocks. 
Pertanyaanya adalah apakah pasar saham tidak efisien? Dalam sudut pandang value investing, pasar saham dinilai kurang efisien. Miss pricing valuation menyebabkan harga saham dihargai terlalu mahal dan terlalu murah. Value investor percaya bahwa saham-saham value stocks dalam posisi undervalued dan akan menghasilkan tingkat pengembalian yang lebih tinggi pada periode berikutnya. Yeh dan Hsu (2014) mengatakan bahwa saham-saham value stocks dan growth stocks mengalami gejala over-reaction sehingga harga saham dihargai terlalu murah atau terlalu mahal berdasar fundamentalnya.

Bondt dan Thaler (1985) mengatakan jika harga saham sistematis over-shoot, maka pembalikan harga saham bisa diprediksi hanya dengan data rata-rata return saham pada masa lalu tanpa melihat fundamentalnya. Pertanyaannya selanjutnya adalah apakah saham-saham value stocks lainnya yang masih mengalami penurunan kinerja akan tetap menghasilkan tingkat pengembalian yang lebih tinggi dibanding saham-saham growth stocks? Saham-saham value stocks tersebut disebut dengan purely value stocks.

Dalam konsep pasar efisien mengatakan bahwa setiap informasi yang relevan akan terserap secara cepat dalam harga saham. Jika kinerja perusahaan memburuk maka saham juga dihargai lebih rendah. Walaupun berdasarkan penelitian-penelitian terdahulu, justru sahamsaham value stocks menghasilkan tingkat pengembalian yang lebih tinggi dibanding sahamsahm growth stocks.

\section{KAJIAN PUSTAKA DAN HIPOTESIS}

Valuasi saham dibagi dua yakni value stocks (dihargai murah) dan growth stocks (dihargai mahal). Growth stocks merupakan saham-saham perusahaan yang memiliki potensi pertumbuhan pendapatan dan laba yang tinggi (Zarowin, 1990) dan mencerminkan optimisme (Piotroski dan Eric, 2012) sehingga dihargai lebih mahal. Sedangkan value stocks merupakan saham-saham perusahaan yang memiliki pertumbuhan pendapatan dan laba yang rendah pada masa lalu (Lakonishok et al., 1994) serta mengalami masalah dengan kinerja keuangan (Fama dan French, 1992) sehingga dihargai lebih murah.

Jika merujuk literatur, sebagian besar penelitian-penelitian terdahulu yang mengatakan bahwa value stocks menghasilkan tingkat pengembalian yang lebih tinggi dibanding value stocks. Bondt dan Thaler (1985) mengatakan bahwa saham-saham loser pada 5 tahun sebelumnya akan mengungguli tingkat pengembalian (return) saham-saham winner pada periode selanjutnya. Capaul et al. (1993) melakukan penelitian pada enam negara (Prancis, Jerman, Swiss, Inggris, Jepang dan Amerika Serikat). Hasilnya menunjukkan bahwa sahamsaham value stocks mengungguli kinerja (return) saham-saham growth stocks pada setiap negara setelah melakukan penyesuaian atas faktor risiko.

Fama dan French (1998) juga mengatakan dalam penelitiannya pada 13 pasar saham utama dan 16 pasar saham di negara-negara berkembang bahwa saham-saham value stocks mengungguli kinerja (tingkat pengembalian) saham-saham growth stocks pada periode 19751995. Begitu juga Bouman et al. (1998) pada 21 negara pada periode 1986-1996 dimana hasilnya menunjukkan bahwa value stocks mengungguli growth stocks.

Athanassakos dan Ivey (2009) melakukan pengujian pada pasar saham di Kanada. Hasilnya terdapat value premium yang kuat pada periode 1985-2002 dalam berbagai kondisi ekonomi. Athanassakos dan Ivey (2009) juga mengatakan bahwa value premium tidak terjadi pada industri tertentu tetapi pada semua industri. Penelitian dari Cordeiro dan Machado (2013) di Brazil juga menunjukkan bahwa value stocks menghasilkan tingkat pengembalian yang lebih tinggi dibanding growth stocks di bursa efek Brazil. Pada negara-negara berkembang, Marjo 
dan Pitkanen (2011) mengatakan bahwa terdapat value premium pada 12 negara berkembang yakni Brazil, Chile, China, India, Indonesia, Malaysia, Meksiko, Filipina, Polandia, Afrika Selatan, Taiwan dan Turki terutama dalam penelitian yang dilakukan pada periode 2001-2011.

Hasil bertolak belakang dikemukakan oleh Beneda (2003). Beneda (2003) mengatakan bahwa pada jangka panjang, saham-saham growth stocks ternyata justru mengungguli sahamsaham value stocks. Value stocks menghasilkan return yang lebih tinggi dibanding growth stocks hanya pada periode periode 5 tahun awal setelah pembentukan portofolio.

Terdapat beberapa penjelasan mengapa kinerja (return) value stocks mengungguli kinerja (return) growth stocks.

1. Fama dan French $(1992,1995)$ mengatakan bahwa value stocks mengungguli kinerja (return) growth stocks karena saham-saham value stocks tersebut lebih berisiko dibanding saham-saham growth stocks yang mengalami masalah dengan kinerja keuangan perusahaan (financial distress).

2. Lakonishok et al., 1994 mengatakan bahwa value stocks mengungguli growth stocks karena investor bereaksi berlebihan (over-reaction) terhadap suatu informasi. Bondt dan Thaler (1985) mengatakan jika harga saham sistematis over-shoot, maka pembalikan harga saham bisa diprediksi hanya dengan data rata-rata return saham pada masa lalu tanpa melihat fundamentalnya.

Sebagian besar penelitian-penelitian terdahulu hanya menguji tingkat pengembalian value stocks tanpa membedakan perubahan kinerja keuangan di masa depan. Piotroski dan Eric (2012) mengatakan jika growth stocks mencerminkan optimisme dan value stocks mencerminkan pesimisme, maka harus terjadi kecocokan antara value stocks dan growth stocks dengan fundamental perusahaan. Dalam konsep pasar yang efisien, harga saham merupakan cerminan dari informasi terkait yang masuk dan mempengaruhi harga saham. Harga saham akan naik jika terdapat informasi yang bagus. Di sisi lain harga saham harga saham akan turun ketika terdapat informasi yang tidak diharapkan.

Dengan setting yang berbeda, pertanyaan yang muncul adalah apakah saham-saham value stocks yang tetap mengalami penurunan kinerja (pada periode selanjutnya) akan menghasilkan tingkat pengembalian yang lebih tinggi dibanding growth stock? Dengan kata lain apakah saham-saham purely value stock tersebut akan mengalami koreksi positif.

Jika merujuk pada sebagian besar literatur-literatur terdahulu walaupun tanpa mempertimbangkan perubahan fundamental, saham-saham value stocks mengungguli kinerja (tingkat pengembalian) saham-saham growth stocks. (Basu, 1977; Bouman, 1998; Capaul et al., 1993; Fama dan French, 1992, 1995, 1998, 2008; Lakonishok et al.,1994, 2004). Akan tetapi Bondt dan Thaler (1985) sendiri mengatakan bahwa jika harga saham secara sistematis overshoot, maka pembalikan harga saham bisa diprediksi hanya dengan data rata-rata return saham pada masa lalu tanpa melihat perubahan fundamentalnya (earning). Berdasarkan literatur dan kajian teeori maka dapat dihipotesiskan sebagai berikut :

\section{Hipotesis}

Purely Value stocks mengungguli tingkat pengembalian purely growth stocks

Purely value stocks (Chahine, 2008) adalah saham-saham value stocks dengan fundametal yang buruk disebut. Sedangkan saham-saham purely growth stocks adalah growth stocks dengan fundamental yang baik. Saham-saham growth stocks dengan fundamental yang buruk disebut dengan overvalued growth stocks. Berikut ini adalah tabel yang menjelaskan hubungan antara 
valuasi saham dengan fundamentalnya.

Tabel 1 Hubungan Antara Valuasi Saham Dengan Fundamental

\begin{tabular}{|c|c|c|}
\hline & High Earning & Low Earning \\
\hline Value Stock & Undervalued value stock & Purely value stock \\
\hline Growth Stock & Purely growth stock & Overvalued growth stock \\
\hline
\end{tabular}

Berdasarkan fundamentalnya dibagi menjadi saham dengan fundamental yang baik dan buruk. Faktor fundamental lain yang digunakan dalam penellitian ini adalah tingkat pertumbuhan laba (earning growth). Tingkat pertumbuhan laba dapat digunakan untuk digunakan untuk memperkirakan besarnya pengembalian saham (Fama dan French, 2002). Drechler (2011) juga mengatakan bahwa pertumbuhan laba merupakan faktor kuat yang dapat mempengaruhi harga saham.

\section{METODE PENELITIAN}

Populasi dari penelitian ini berasal dari Bursa Efek Indonesia. Data yang digunakan antara lain stocks return, market return, fundamental perusahaan (earning grwoth) serta valuasi saham (PER). Portofolio dibentuk setiap tahun dengan metoda annual rebalancing. Pembentukan portofolio dilakukan pada t-1 yang dimulai dari tahun 2002 sampai 2013. Sedangkan pengujian dilakukan pada $t+1$ yang dimulai dari tahun 2003-2014. Berikut ini adalah penjelasan variabel yang digunakan dalam penelitian ini :

1. Stocks return

Stocks return merupakan tingkat pengembalian saham yang dihitung berdasarkan selisih antara harga saham pada tahun $t$ dengan harga saham pada tahun $\mathrm{t}-1$.

\section{Fundamental}

Dalam penelitian ini, peneliti menggunakan earning growth yang menunjukkan seberapa besar tingkat pertumbuhan laba perusahaan pada tahun t dibandingkan dengan tahun sebelumnya (t-1). Perhitungan earning growth digunakan nilai absolute untuk mencegah terjadinya kesalahan kalkulasi. Data earning growth yang digunakan adalah data tahunan dari tahun 2003-2014.

3. Valuation

Valuasi saham yang digunakan yakni price to earning (PER) pada t-1 dari tahun 2002 sampai 2013. PER dihitung secara manual dengan membagikan earning (laba bersih) dengan kapitalisasi pasar. Peneliti hanya menggunakan PER sebagai valuasi saham karena PER merupakan valuasi saham yang paling sering digunakan

\section{Pengujian Hipotesis}

Saham-saham value stocks ditunjukkan dengan PER paling rendah (persentil ke-30). Sedangkan saham-saham growth stocks ditunjukkan dengan PER paling tinggi (persentil ke70). Saham-saham high earning ditunjukkan dengan earning growth yang rendah (persentil ke30). Sedangkan saham-saham low earning ditunjukkan dengan earning growth yang tinggi (persentil ke-70).

Untuk menguji hipotesis, peneliti membentuk portofolio yang merupakan cross sextion antara valuasi saham (value stocks dan growth stocks) dengan perubahan fundamental saham yang terjadi pada $\mathrm{t}+1$ (earning growth) sebagai berikut :

1. Purely value stocks : value stocks dengan low earning.

2. Purely growth stocks : growth stocks dengan high earning. 
Hipotesis diterima jika saham-saham purely value stocks menghasilkan tingkat pengembalian yang lebih tinggi dibandingkan purely growth stocks. Artinya juga terdapat gejala over-reaction pada saham-saham value stocks. Akan tetapi apabila hipotesis ditolak, menunjukkan bahwa pasar saham dalam keadaan efisien dimana saham-saham value stocks menghasilkan tingkat pengembalian yang rendah karena kinerja perusahaan tetap memburuk pada $t+1$. Uji statistik yang digunakan adalah uji beda independent sample t-test..

\section{HASIL DAN PEMBAHASAN}

Dalam penelitian ini, saham-saham growth stocks mempunyai PER berkisar antara 7,79 sampai 32.18. Sedangkan saham-saham value stocks mempunyai PER rata-rata berkisar antara $-0,37$ sampai 8.05. Valuasi tertinggi growth stocks terjadi pada tahun 2007 dengan nilai PER sebesar 32,18. Valuasi terendah growth stocks dijumpai pada tahun 2002 dan tahun 2004 baik untuk value stocks dan growth stocks.

Grafik 1 PER Value Stocks \& Growth Stocks

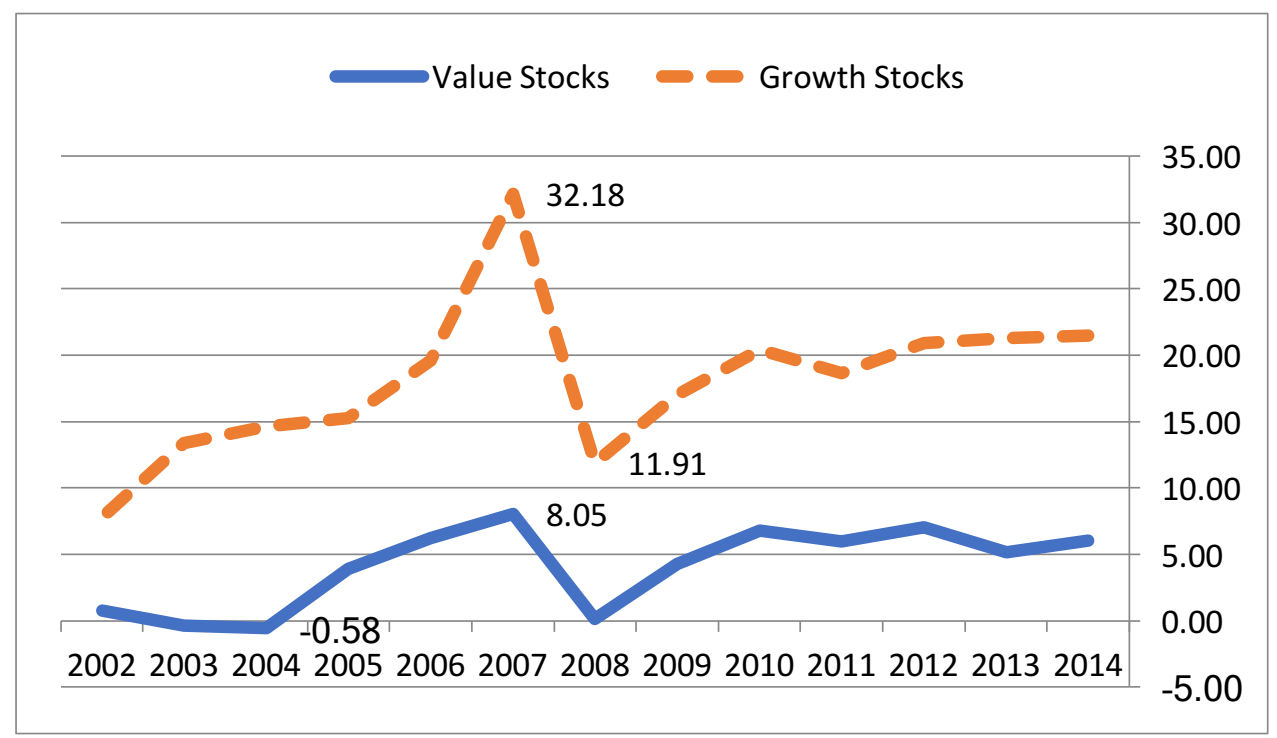

Berdasarkan kapitalisasinya, saham-saham growth stocks mempunyai kapitalisasi pasar yang lebih besar dibanding saham-saham value stocks Kapitalisasi pasar menunjukkan seberapa besar perusahaan tersebut dihargai oleh pasar di pasar modal yang dihitung dari harga saham dikalikan jumlah saham yang beredar.

Tabel 1 Karakteristik Value Stocks \& Growth Stocks Berdasarkan Kapitalisasi

\begin{tabular}{|c|c|c|}
\hline Tahun & Value Stocks & Growth Stocks \\
\hline 2014 & 1.853 .375 .355 .356 & 12.952 .734 .053 .454 \\
\hline 2013 & 1.954 .114 .435 .294 & 10.952 .778 .114 .090 \\
\hline 2012 & 909.198 .747 .728 & 9.089 .489 .610 .945 \\
\hline 2011 & 944.945 .409 .028 & 8.545 .522 .329 .955 \\
\hline 2010 & 753.448 .415 .573 & 4.660 .916 .535 .325 \\
\hline 2009 & 650.660 .402 .068 & 3.857 .259 .964 .504 \\
\hline
\end{tabular}




\begin{tabular}{|c|c|c|}
\hline 2008 & 337.929 .298 .161 & 3.949 .499 .814 .580 \\
\hline 2007 & 512.958 .989 .786 & 4.990 .678 .219 .128 \\
\hline 2006 & 278.511 .367 .761 & 4.337 .444 .402 .008 \\
\hline 2005 & 330.627 .932 .054 & 3.303 .666 .367 .453 \\
\hline 2004 & 193.836 .415 .893 & 2.461 .455 .900 .672 \\
\hline 2003 & 177.068 .621 .014 & 1.473 .037 .007 .329 \\
\hline Rata-rata & 741.389 .615 .810 & 5.881 .206 .859 .954 \\
\hline
\end{tabular}

\section{Analisis Data : Value Stock VS Growth Stocks}

Total sampel saham-saham value stocks sebanyak 959 saham dan growth stocks sebanyak 976 saham. Jumlah sampel tiap tahun berbeda karena disesuaikan dengan jumlah saham yang listing. Berikut ini adalah tabel yang menunjukkan tingkat pengembalian saham value stocks dan growth stocks :

Tabel 2 Tingkat Pengembalian Value Stocks \& Growth Stocks

\begin{tabular}{|c|c|c|c|c|c|c|}
\hline \multirow[b]{2}{*}{ Periode } & \multirow{2}{*}{ Tahun } & \multicolumn{2}{|c|}{ Value Stocks } & \multicolumn{2}{|c|}{ Growth Stocks } & \multirow{2}{*}{$\begin{array}{c}\text { Value } \\
\text { Premium }\end{array}$} \\
\hline & & Sampel & Return & Sampel & Return & \\
\hline 1 & 2014 & 117 & 0.268 & 118 & 0.038 & 0.230 \\
\hline 2 & 2013 & 115 & 0.283 & 116 & 0.089 & 0.193 \\
\hline 3 & 2012 & 111 & 0.414 & 112 & 0.310 & 0.103 \\
\hline 4 & 2011 & 105 & 0.354 & 106 & 0.190 & 0.164 \\
\hline 5 & 2010 & 97 & 0.716 & 97 & 0.594 & 0.121 \\
\hline 6 & 2009 & 92 & 0.275 & 96 & 0.323 & -0.048 \\
\hline 7 & 2008 & 86 & -0.187 & 88 & -0.383 & 0.195 \\
\hline 8 & 2007 & 55 & 0.940 & 55 & 1.701 & -0.760 \\
\hline 9 & 2006 & 44 & 0.396 & 49 & 0.353 & 0.042 \\
\hline 10 & 2005 & 43 & 0.064 & 47 & -0.047 & 0.112 \\
\hline 11 & 2004 & 48 & 0.454 & 48 & 0.149 & 0.304 \\
\hline \multirow[t]{2}{*}{12} & 2003 & 46 & 0.793 & 44 & 0.250 & 0.543 \\
\hline & \multicolumn{2}{|c|}{ Rata-rata } & 0.398 & & 0.297 & \\
\hline
\end{tabular}

Value premium menunjukkan selisih antara tingkat pengembalian value stocks dengan growth stok. Berdasarkan tabel di atas menunjukkan bahwa rata-rata value stocks menghasilkan tingkat pengembalian yang lebih tinggi (39,8\%) dibandingkan growth stocks $(29,7 \%)$ yakni 10 kali dari 12 periode. Value premium tertinggi terjadi pada tahun 2003 yakni sebesar 54,3\%. Secara statistic hasil uji beda independen t test dapat diuraikan dalam tabel berikut : 
Tabel 3 Independent Samples Test

\begin{tabular}{|l|c|c|c|r|}
\hline & $\mathrm{F}$ & Sig. & $\mathrm{T}$ & Sig. (2-tailed) \\
\hline Equal variances assumed & 3.812 & .051 & 1.818 & .069 \\
\hline Equal variances not assumed & & & 1.818 & .069 \\
\hline
\end{tabular}

Hasil uji beda tersebut menunjukkan bahwa sedikit terdapat perbedaaan dengan signifikansi 0,069 (kurang signifikan). Dengan kata lain jika melihat statistik, tidak terdapat perbedaan yang signifikan antara tingkat pengembalian value stocks dan growth stocks.

\section{Analisis Data : Purely Value Stoc \& Purely Growth Stocks}

Dengan sudat pandang yang berbeda, peneliti kemudian menguji apakah saham-saham value stocks tersebut tetap menghasilkan tingkat pengembalian saham yang lebih tinggi dibanding growth stocks kendati tetap mengalami penurunan kinerja pada periode selanjutnya. Peneliti menggunakaan PER sebagai valuasi saham pada periode t-1 dan tingkat pertumbuhan laba pada $t+1$. Saham-saham value stocks yang dipilih hanyalah saham-saham value stocks yang mengalami penurunan kinerja pada periode $\mathrm{t}+1$.Sedangkan saham-saham growth stocks yang dipilih hanyalah saham-saham growth stocks yang mengalami kenaikan kinerja yang baik pada periode t+. Dalam penelitian ini, saham-saham high earning mempunyai rata-rata tingkat pertumbuhan laba sebesar $45 \%$ sampai $99 \%$ per tahun. Sedangkan saham-saham low earning mempunyai tingkat pertumbuhan laba berkisar antara -18\% sampai 5\% per tahun.

Jumlah sampel untuk purely value stocks sebesar 290 dan purely growth stocks sebesar 255. Berikut ini adalah tabel yang menunjukkan tingkat pengembalian saham saham-saham value stocks dan growth stocks yang telah disesuaikan dengan perubahan tingkat pertumbuhan laba :

Tabel 4 Tingkat Pengembalian Value Stocks \& Growth Stocks Setelah Disesuaikan Perubahan Laba

\begin{tabular}{|c|c|c|c|c|c|c|}
\hline \multirow{2}{*}{ Periode } & \multirow{2}{*}{ Tahun } & \multicolumn{2}{|c|}{$\begin{array}{c}\text { Purely Value } \\
\text { Stocks }\end{array}$} & \multicolumn{2}{c|}{$\begin{array}{c}\text { Purely Growth } \\
\text { Stocks }\end{array}$} & \multirow{2}{*}{$\begin{array}{c}\text { Value } \\
\text { Premium }\end{array}$} \\
\cline { 3 - 6 } & & Sampel & Return & Sampel & Return & \\
\hline 1 & 2014 & 33 & 0.023 & 32 & 0.153 & -0.130 \\
\hline 2 & 2013 & 39 & 0.099 & 42 & 0.257 & -0.158 \\
\hline 3 & 2012 & 41 & 0.005 & 43 & 0.351 & -0.346 \\
\hline 4 & 2011 & 38 & 0.028 & 41 & 0.371 & -0.343 \\
\hline 5 & 2010 & 32 & 0.277 & 48 & 1.020 & -0.743 \\
\hline 6 & 2009 & 15 & 0.359 & 39 & 0.502 & -0.143 \\
\hline 7 & 2008 & 29 & -0.327 & 25 & -0.388 & 0.061 \\
\hline 8 & 2007 & 17 & 0.823 & 24 & 1.210 & -0.387 \\
\hline 9 & 2006 & 10 & 0.269 & 12 & 0.907 & -0.638 \\
\hline 10 & 2005 & 10 & -0.196 & 15 & 0.053 & -0.249 \\
\hline 11 & 2004 & 11 & 0.54 & 18 & 0.288 & 0.252 \\
\hline 12 & 2003 & 15 & 0.875 & 16 & 0.771 & 0.104 \\
\hline
\end{tabular}




\begin{tabular}{|l|l|l|l|l|} 
& Rata-rata & 0.231 & & 0.458 \\
\hline
\end{tabular}

Berbeda dengan hasil sebelumnya, setelah disesuaikan dengan perubahan laba, purely growth stocks justru menghasilkan tingkat pengembalian yang lebih tinggi $(45,8 \%)$ dibandingkan purely value stocks. Saham-saham value stocks menghasilkan tingkat pengembalian saham yang rendah terutama jika saham-saham perusahaan tersebut kembali mengalami penurunan kinerja pada $\mathrm{t}+1$. Dalam konsep pasar efisien, informasi yang terkait mencerminkan dan mempengaruhi harga saham. Ketika laporan keuangan perusahaan kurang memuaskan maka harga saham akan turun.

Lebih jauh berikut ini hasil uji beda independen sample $t$ test yang menunjukkan perbedaan tingkat pengembalian saham (return) antara saham-saham value stocks dengan growth stocks setelah disesuaikan dengan perubahan tingkat laba :

Tabel 5 Independen Sample T test

\begin{tabular}{|l|c|c|c|c|}
\hline & $\mathrm{F}$ & $\mathrm{T}$ & $\begin{array}{c}\text { Sig. (2- } \\
\text { tailed) }\end{array}$ & $\begin{array}{c}\text { Mean } \\
\text { Difference }\end{array}$ \\
\hline Equal variances assumed & 8.624 & -3.510 & .000 & -.30634 \\
\hline Equal variances not assumed & & -3.601 & .000 & -.30634 \\
\hline
\end{tabular}

Berdasarkan tabel 3.5 di atas menunjukkan bahwa terdapat perbedaan yang sangat signifikan (0.01) dimana saham-saham growth stocks menghasilkan tingkat pengembalian yang lebih tinggi dibanding dengan saham-saham value stocks setelah dilakukan penyesuaian perubahan laba.

Lebih jauh lagi, peneliti kemudian membentuk portofolio untuk melihat perbedaanya lebih jauh lagi dengan hanya membentuk saham-saham value stocks yang mempunyai PER negatif. Saham dengan PER negatif menunjukkan bahwa perusahaan perusahaan mengalami kerugian (laba negatif).

Tabel 6 Tingkat Pengembalian Value Stocks (PER Negatif) \& Growth Stocks Setelah Disesuaikan Perubahan Laba

\begin{tabular}{|c|c|c|c|c|c|c|}
\hline \multirow{2}{*}{ Periode } & \multirow{2}{*}{ Tahun } & \multicolumn{2}{|c|}{ Purely Value } & \multicolumn{2}{c|}{ Purely Growth } & Value \\
\cline { 3 - 7 } & & Sampel & Return & Sampel & Return & \\
\hline 1 & 2014 & 18 & -0.097 & 32 & 0.153 & -0.25 \\
\hline 2 & 2013 & 18 & 0.292 & 42 & 0.257 & 0.035 \\
\hline 3 & 2012 & 23 & -0.11 & 43 & 0.352 & -0.462 \\
\hline 4 & 2011 & 18 & -0.017 & 41 & 0.371 & -0.388 \\
\hline 5 & 2010 & 16 & -0.122 & 48 & 1.021 & -1.143 \\
\hline 6 & 2009 & 13 & 0.333 & 39 & 0.502 & -0.169 \\
\hline 7 & 2008 & 18 & -0.351 & 25 & -0.388 & 0.037 \\
\hline 8 & 2007 & 10 & 1.114 & 24 & 1.211 & -0.097 \\
\hline 9 & 2006 & 3 & -0.194 & 12 & 0.908 & -1.102 \\
\hline 10 & 2005 & 11 & -0.142 & 15 & 0.053 & -0.195 \\
\hline 11 & 2004 & 11 & 0.541 & 18 & 0.288 & 0.253 \\
\hline
\end{tabular}




\begin{tabular}{|l|c|c|c|c|c|c|}
12 & 2003 & 8 & -0.04 & 16 & 0.771 & -0.811 \\
\hline & Average & & 0.101 & & 0.458 & -0.357 \\
\hline
\end{tabular}

Berdasarkan tabel 7 di atas, saham-saham purely value stocks dengan PER negatif menghasilkan rata-rata tingkat pengembalian $(10,1 \%)$ lebih kecil dari tingkat pengembalian purely gorwth stocks $(45,8 \%)$ yang ditunjukkan dengan value premium yang negatif .Untuk lebih jelasnya, berikut ini adalah hasil uji beda :

Tabel 7 Independen Sample T test

\begin{tabular}{|l|c|c|c|r|}
\hline & $\mathrm{F}$ & Sig. & $\mathrm{T}$ & \multicolumn{1}{c|}{ Sig. (2-tailed) } \\
\hline Equal variances assumed & 7.440 & .007 & -3.601 & .000 \\
\hline Equal variances not assumed & & & -3.843 & .000 \\
\hline
\end{tabular}

Berdasarkan tabel di atas menunjukkan bahwa terdapat perbedaan yang sangat signifikan dengan taraf signifikansi kurang dari 0.01. Saham-saham growth stocks menghasilkan tingkat pengembalian yang lebih tinggi dibanding dengan saham-saham value stocks setelah dilakukan penyesuaian perubahan laba.

\section{Pembahasan : Purely Value Stoc \& Purely Growth Stocks}

Bondt dan Thaler (1985) mengatakan jika harga saham secara sistematis over-shoot, maka pembalikan harga saham bisa diprediksi hanya dengan data rata-rata return saham pada masa lalu tanpa melihat fundamentalnya (earning). Dalam penelitiannya, Bondt dan Thaler (1985) menunjukkan bahwa saham-saham dengan P/E yang rendah akan mendapatkan tingkat pengembalian yang lebih tinggi dibanding saham dengan P/E yang tinggi. Penjelasan anomali adanya fenomena over-reaction tersebut disebut dengan price to earning hypothesis.

Dengan setting yang berbeda penelilti mempertimbangkan perubahan laba pada $\mathrm{t}+1$. Tujuan penelitian ini adalah menguji apakah saham-saham value stocks akan menghasilkan tingkat penegembalian yang lebih tinggi dibandingkan saham-saham growth stocks tetap kendati mengalami kinerja keuangan. Hasilnya menunjukkan bahwa tanpa memperhatikan perubahan fundamental, value stock menghasilkan tingkat pengembalian yang lebih tinggi dibanding growth stocks walaupun kurang signifikan (0.06). Akan tetapi setelah disesuaikan dengan perubahan laba, saham-saham purely value stocks menghasilkan tingkat pengembalian yang lebih rendah dibanding saham-saham purely growth stocks dengan tingkat signifikansi 0.01 .

Menurut Lakonishok et al. (1997), Piotroski (2000), Yan dan Zhao (2011) bahwa sahamsaham value stocks akan menghailkan tingkat pengemblian yang lebih tinggi jika disertai kejutan positif atau perubahan yang positif dalam hal arus kas dan laba perusaahaan. Artinya jika kinerja saham-saham value stocks tersebut tetap memburuk maka tingkat pengembalian yang diterima juga akan rendah. Sesuai dengan konsep pasar efisien menyebutkan bahwa harga saham mencerminkan setiap informasi yang relevan dan terserap secara cepat dalam perubahan harga saham. Artinya ketika kinerja perusahaan memburuk maka tingkat pengembalian yang diterima juga akan rendah.

\section{PENUTUP}

Saham-saham value stocks menghasilkan tingkat pengembalian yang lebih tinggi dibanding 
saham-saham growth stocks dengan tingkat signifikansi 0.069. Dari 12 periode pengujian, portofolio value stocks mengungguli portofolio growth stocks sebanyak 10 kali kecuali pada tahun 2007 dan 2009 dengan value premium sebesar 10,1\% tiap tahun.

Setelah disesuaikan dengan perubahan perubahan laba menunjukkan hasil yang berbeda. Saham-saham growth stocks dengan kinerja baik (purely growth stocks) menghasilkan tingkat pengembalian yang lebih tinggi dibandingkan dengan saham-saham value stocks yang berkinerja buruk (purely value stocks) dengan tingkat signifikansi di bawah 0.01 dengan value premium sebesar $37,5 \%$ tiap tahun.

\section{DAFTAR PUSTAKA}

Athanassakos, G. \& Ivey, R. 2009. Value vs. Glamour StocksReturn And the Value Premium : The Canadian Experience 1985-2002. Canadian Journal of Administrative Science.

Basu, S. 1977. Investment Performance of Common Stocks in Relation to Their Size-Earnings Ratios : A Test of the Efficient Market Hypothesis. The Journal of Finance, Vol. 32, No. 3.

Bauman, W.S. \& Miller, R.E. 1997. Investor Expectations And The Performance Of Value Stocks Versus Growth Stocks. Journal of Portfolio Management.

Bauman, W.S., Conover, C.M., \& Miller, R.E. 1998. Growth Versus Value and Large-Cap Versus Small-Cap Stocks in International Markets. Financial Analysts Journal.

Beneda, N. 2003. Growth StocksOutperform Value Stocks over Long Term. Academy of Accounting and Finncial Studies Journal.

Bondt, W.F.M.D. \& Thaler, R. 1985. Does the StocksMarket Overreact? The Journal of Finance, Vol. 40, No. 3.

Capaul, C., Rowley, I., \& Sharpe, W.F. 1993. International Value and Growth StocksReturn. Financial Analyst Journal.

Chahine, S. 2008. Value Versus Growth Stocksand Earnings Growth in Style Investing Strategues in Euro-Markets. Journal of Assets Management,

Chordia, T. \& Swaminatan, B. 2000. Trading Volume and Cross-Autocorrelations in StocksReturns. The Journal of Finance. Vol. LV, No. 2.

Drechsler, F.S. 2011. Yes, Earnings Do Drive StocksSizes. Quantitative Research Manager/Portfolio Manager. Bob Turner.

Fama, E.F. 1970. Efficient Capital Markets: A Review of Theory and Empirical Work. Journal of Finance, Volume 25, Issue 2.

Fama, E.F. \& French. K.R, 1974. Random Walks in StocksMarket Prices. Financial Analysis Journal.

Fama, E.F. \& French, K.R. 1995. Size and Book-to-Market Factors in Earnings and Returns. The Journal of Finance.

Fama, E.F. \& French, K.R. 1998. Value versus Growth: The International Evidence. The Journal of Finance.

Fama, E.F. \& French, K.R. 2002. The Equity Premium. The Journal of Finance.

Fama, E.F. \& French, K.R. 2008. Average Returns, B/M, and Share Issues. The Journal of Finance.

Lakonishok, J., Shleiver, A., \& Vishny, R.W. 1994. Contrarian Investment, Extrapolation, and Risk. The Journal of Finance.

Lakonishok, J., Porta, R.L, Shleifer, A., Vishny, R. 1997. Good News For Value Stocks: Further 
Evidence On Market Efficiency. The Journal of Finance.

Leledakis, G. \& Davidson, I. 2001. Are two factors enough? The UK evidence, Financial Analysts Journal 57, 96-105.

Marjo \& Pitkanen, R.E. 2011. Value Investing in Emerging Market. Copenhagen Business School. Finance and Strategic Management.

Piotroski, J.D. 2000. Value investing: The Use of Historical Financial Statement Information To Separate Winners From Losers. Journal of Accounting Research 38:1-41.

Piotroski, J.D. \& Eric, C. 2012. Identifying Expectation Errors in Value/Glamour Strategies: A Fundamental Analysis Approach. Forthcoming in the Review of Financial Studies.

Yan, Z. \& Yao, Y. 2011. When Two Anomalies Meet: The Post-Earnings Announcement Drift And The Value-Glamour Anomaly. Financial Analalysist Journal.

Yeh, I.C. \& Hsu, T.H. 2014. Exploring The Dynamic Model Of The Return From Value Stocks And Growth Stocks Using Time Series Mining. Elsevier.

Zarowin, P. 1990. What Determines Earnings-Price Ratios: Revisited. Journal of Auditing, Accounting and Finance, 5(3), 439-457. 